\title{
Woody Allen Sinemasında Bir Iletișim Mekânı Olarak Banklar
}

\author{
Serdar Öztürk ${ }^{1}$ \\ Ișkın Özbulduk Kılıç²
}

\begin{abstract}
ÖZ
Kent mobilyaları, kent mekânlarında, insanların kentle ve birbirleriyle iletişim kurdukları iletişim mekânlarıdır. Çeşitli amaçlar ve şekillerde üretilen bu kent mobilyaları, insanlara bekleme, dinlenme, buluşma gibi kent içi etkinlikleri gerçekleştirme olanağı sağlarken, aslında kamusal mekân içerisinde yarı- kamusal alan yaratmaktadırlar. Bireyler bu yarı-kamusal mekânlarda, kamusal alanda olduğundan daha farklı bir iletişim biçimi geliştirirler. Kentin ve kent mobilyalarının bu olanaklarının Woody Allen sinemasında özel bir yeri vardır. Bu çalışma, Woody Allen sinemasında, karakterlerin iletişim mekânı olarak kullandıkları kent mobilyalarından, özellikle bankların, kullanım amaç ve biçimlerini incelemektedir. Bu inceleme, Woody Allen sinemasından seçilmiş on iki film üzerine gerçekleştirilmiştir. Seçilmiş filmlerde kullanılan kent mobilyaları aracılığıyla, bu mekânlarda gerçekleştirilen iletişim biçimlerinin, karakterler ve onların senaryodaki konumlarıyla olan ilişkisi üzerinde durulmuştur. Bunun yanında, kent mobilyalarının sinemadaki ve gerçek kent mekânlarındaki kullanımları arasındaki ilişki de araştırılmıştır.
\end{abstract}

Anahtar Kelimeler: Kent Mobilyaları, Woddy Allen, Kent, Sinema

\section{Benches As A Communication Space In Woody Allen Cinema}

\begin{abstract}
City furnishings are the communication spaces where people communicate with the city and each other in urban spaces. These urban furnishings, which are produced for various purposes and in various forms, provide people with the opportunity to perform in-city activities such as waiting, resting and meeting, while creating semi-public spaces within public spaces. Individuals develop a different form of communication in these semi-public spaces compared to public spaces. The opportunities offered by city and city furnishings have a special place in Woody Allen cinema. This study examines the purpose and the forms of city furnishings, especially the benches, used by the characters as communication space in Woody Allen cinema. Twelve movies of Woody Allen were analysed for the study. Through the benches used in the selected movies, the relationship of the forms of communication held in these spaces with the characters and their positions in the scenario is emphasized. In addition, the relationship between the use of city furnishings in cinema and in real urban spaces has also been examined in the study.
\end{abstract}

Keywords: City Furnishings, Woody Allen, City, Cinema

1 Prof. Dr., Gazi Üniversitesi, İletişim Fakültesi Radyo TV ve Sinema Bölümü

2 Doktora öğrencisi, Gazi Üniversitesi, İletişim Fakültesi Radyo TV ve Sinema Bölümü 


\section{Giriș}

\section{Kent Mobilyalarının Mekânsal Niteliği}

$\mathrm{K}$ ent mobilyalarını, birer iletişim mekânı olarak tanımlamadan önce mekânsallığı üzerinde durmak gereklidir. Bu çalışma, kapsamında kent mobilyaları, kentin içerisinde konumlandırılmış, kentsel mekânda içkin bir mekân olarak ele alınmıştır. Kent mekânları ise kamusal alanlar, yarı kamusal alanlar ve özel alanlarla çevrili, çoklu mekânsal katmanlara sahip yapıda mekânlar olarak belirlenmiştir.

Kamusal alan kavramı oldukça geniş, kapsamlı ve farklı boyutları olan bir kavramdır. "Kamu" ve "kamusallığın" anlamları üzerinde de bir uzlaşım sağlanamadığından onlardan türeyen kamusal alan kavramının da tanımı sabitlenememiştir. Kamu kelimesini günlük hayatta oldukça sık ve daha çok devlet ile ilişkilendirilen mekânlardan söz ederken kullanılmaktadır. Oysa, kelimenin anlamları üzerinde durulduğunda kamu kavramıyla daha çok halktan söz edildiği görülmektedir. Gündelik yaşamdaki kullanım biçimleri incelendiğinde ise çoğu zaman birbiri ile uyuşmayan tanımlarla ve anlamsal problemlerle karşılaşılmaktadır. Türk Dil Kurumu'nun anlamlandırmasına göre kamu, "bir ülkedeki halkın bütünü, halk, amme" ve "halk hizmeti gören devlet organlarının tümü" olarak yine ikili bir biçimde tanımlanmaktadır (ww.tdk.gov.tr). Sözlük anlamından yola çıkıldığında 'kamu' ve 'kamusal' kavramlarının içerisinde 'herkese açık olma' vurgusu barındırdığı kolayca anlaşılmaktadır. "Kamu" ve "kamusal" kavramlarının kökenlerini Antik Yunan'daki felsefi tartışmalara dek götürmek olasıdır. Batı toplumlarında geç ortaçağ ve erken modern dönemlerde "kamu" kavramı ve zıddını oluşturan "özel" kavramı, değişen kurumsal yapılarla birlikte anlamını bulmuştur. 15. Yüzyıl itibariyle kamu, devletten kaynaklanan, devletle ilgili olan ve içerisinde otoriteyi barındıran bir kavram halini almıştır. Bu aşamada özel, ise devlet ile ilgisi olmayan faaliyetler ile yine devletin otoritesinin olmadığı yaşam alanlarını ifade etmektedir. (Thapmson, 2008: 185-186). Modern anlamıyla ise kamu 17. Yüzyıl'dan itibaren Batı tarihinde varlığını sürdüren ve burjuva toplumuna ait bir kavramdır (Özbek, 2004: 43). Bunun yanında 19. Yüzyıl'ın sonlarından itibaren iki kavram arasındaki sınır giderek bulanıklaşmıştır. Bu dönemde özel alan, resmi olmayan veya hukuk tarafından onaylanmış kişisel, ailevi ilişkiler sahası olarak tanımlanırken, kamu alanı devletin kurumsal yapılaşmasını barındıran, aynı zamanda devletin elindeki ekonomik örgütlenmeleri de içeren kurumları açıklamaktadır (Thopmson, 2008: 187).

Kamusal alan kavramı tanımlanmaya çalışıldığında ise yine çok sayıda ve kimi zaman birbiri ile çelişen tanımlamaların olduğu görülmektedir. ${ }^{3}$ Ancak her bir yaklaşımda

3 Kavram, Habermas tarafından geliştirilmiştir. Bir diğer anlatımla kamusal alan kavramı Habermas'ın çalışmaları ile entelektüel bir kimliğe bürünmeye başlamıştır. Habermas kamusal alan kavramını açıklarken ona tarihsel bir bakış açısı da kazandırmıştır. Habermas'ın kamusal alanı, tek tek özel olan bireylerin bir araya gelerek toplandıklarında bir kamusal gövdeye dönüşmelerinden ve bu sayede de kamusal alanın bir parçası olduklarından söz ederek, bireyin kamusal alandaki ontolojik varlığının altını çizer. Ancak Habermas'ın kastettiği bir aradalık, bireylerin bir iş ilişkisindeki sergiledikleri davranışlardan ve anayasal bir düzenin yasal sınırlamalarla sınırlanmış üyelerinin davranışlarına benzememektedir. Bireylerin, kamusal gövdenin bir parçası olmaları onların kamusal alanda örgütlenmeleri, toplanmaları ve kanaatlerini ifade etmeleri hususlarında özgür olmaları neticesinde gerçekleşir. (Habermas, 2004: 95). Kamusal mekânı yine bireylerin mekânla ve mekândaki ilişkileri üzerinden tanımlayan Sennett ise kamusal alanı insanların belirli mekânlardaki yoğun toplumsal ilişkileri olarak tanımlamaktadır. Ona göre bu toplumsal ilişkiler, insanların başkalarıyla karşılaşarak yaşadıkları samimi deneyimler aracılığı ile bireysel kişiliklerini geliştirebilmelerini sağlamaktadır (Senett, 2002: 43). Kamusal alan kavramı üzerinde çalışmalar yapmış bir diğer düşünür olan Hannah Arendt de Habermas 
"kamusal alan herkese açık bir potansiyele sahiptir" şeklinde bir uzlaşım gözlenmektedir. Bu potansiyel sayesinde kamusal alan toplumsal aktörlerin karşılaşmalarının mekânı olarak belirmektedir. Başka bir deyişle, bireyler toplumsal birer aktör olarak kamusal alanda iletişime geçerler. Bu da kamusal alanların mekânsal somutlaşmasının genellikle kent mekânında gerçekleştiğini anlatır. Bu nedenle, çalışmamızın devamında kamusal alan kavramı yerine, "kentsel mekân" kavramını kullanılacaktır. Özbek'e (2004a: 4041) göre, kamusal mekân kavramı kamusal alan kavramının mekânsal boyutunu oluşturur. Ayrıca, kamusal mekân kavramının odağında kentsel yaşam, sosyallik ve sosyal yaşam gibi olgular vardır. Kentsel mekân kavramı, "mekân" kavramı üzerinde düşünme gerekliliğini getirir. İnsanların yerleşik hayata geçmeleri korunma, barınma ve yaşamsal gereksinimlerini karşılaması amacıyla yapılan faaliyetlerin önem kazanması anlamına gelmiş buna bağlı olarak mekân olgusunun da önemi açığa çıkmıştır. Ortaya çıkan mekân olgusu süreç içerisinde sosyoekonomik, kültürel, fiziksel ve siyasal ilişkiler üzerinden şekillenerek bir yaşam alanı olmuştur. Bu perspektifle bakıldığında mekân olgusu sadece coğrafyacılara bırakılmayacak kadar önemlidir (Sertaç, 2012: 5).

$\mathrm{Bu}$ nedenle, de mekân, birçok bilimsel alanın üzerinde çalıştığı bir çalışma alanı olmuştur. Mekân kavramının etimolojik kökeni Arapça "kevn" kökünden türemektedir. Kevn kelimesinin Türkçe karşılığı "olmak" anlamına gelmektedir. Bu kökenden gelen mekân kelimesi yer, mahal, ev, oturulan yer anlamlarına gelir (Develioğlu, 1992: 721). Mekân, en çok "yer" anlamında kullanılmakla beraber bulunulan çevre, ortam yaşanılan dünya anlamına da gelmektedir (Göka, 2001: 8). Asiliskender'e göre mekânı içinde yaşayanları, dışarıdakilerden ayıran, fiziksel bir somutluk içinde kodlanmış boşluktur. Yazara göre, mekânın fiziksel özellikleri ile oluşan iç-dış ayrımı insanların kimlik kavramına da etki eden temel unsurdur. Yani kimlik düşüncesinin özü mekânsaldır. Mekânlar belleğin içinde saklanan bilgilere göre şekillenen nesneler olup duvarların ardında sadece yaşamak için boşluktan alışkanlıkların kısaca toplum bilgisi ile deneyimi sıkıştırmış yaşam boşluklarıdır (2002: 13). Bu bakış açısıyla mekân insanların yalnızca toplumsal ilişkiler kurduğu bir yer değildir. Mekân hem içinde var olan bedenler tarafından biçimlenen hem de bedenlerin algılarını ve ilişkilerini biçimlendiren dinamik bir organizma gibidir. Lefebvre (2009: 185) mekânın toplumsal üretimin sonucu meydana geldiğini söylemektedir ve bu toplumsal üretim nedeniyle mekân politik ve ideolojiktir. ${ }^{4}$ Öztürk'e göre, bir 'yer' ancak iletişimin uğrak noktası ise ona mekân denilebilmektedir. Öztürk için bir yerin mekân olması onun antropolojik

gibi kamusal alanı herkese açık olması yönüyle tanımlar. Bu kavramın kökenini İnsanlık Durumu adı eserinde Antik Yunan'da bulan düşünür, insanın yaşam içerisinde emek, iş ve eylem olmak üzere üç etkinliği olduğundan söz eder ve bu etkinliklerin gerçekleştirdikleri yerlere göre kamusal alan ve özel alanın nitelemesini yapar. Anlaşılacağı üzere kamusal alanın yanında özel alan kavramından da söz etmek gereklidir. Özel alan ve kamusal alan kavramları varlıklarını birbirlerine borçlu olmakla birlikte, birbirlerinin zıddı olan mekânları ifade etmektedirler. En geniş tanım özel alan kamusal alan olmayan yerdir. Alkan'a göre özel alan ve kamusal alan kavramları birbiri ile ilişkilendirilerek bu kavramlar politik anlamlar yüklenmiştir (1999: 3).

4 Lefebvre mekân ve toplumsal ilişkiler etkileşimine dair üç temel yaklaşım sunmuştur. Bunlardan ilki etkileşimin dışsal bir ilişki olduğunu söyleyen mutlak mekân anlayışıdır. Söz konusu anlayışa göre mekân ve sosyal ilişkiler birbirinden bağımsız oluşmuştur ve mekân yalnızca sosyal ilişkilerin gerçekleştiği bir sahnedir. Mekân ve sosyal olgular birbirinden ayrılırken birbirlerine olan etkileri tartışmanın temel eksenini oluşturmaktadır. İkincisi ise mutlak mekân anlayışına karşı çıkan ve mekânın sosyal olandan ayrı tutulamayacağını öne süren bir anlayıştır. Lefebvre ikinci etkileşimde mekânı fetişleştirmenin aksine mekânın ve sosyal olguların birbirine olan konumlanışları sonucunda mekânın ortaya çıktığını söyler. Üçüncü anlayış ise ilk iki anlayışa eleştiri olarak ortaya çıkmış ilişkisel yaklaşımdır. Bu anlayış mekânı sosyal birimler arası bir ilişki olarak tanımlamaktadır. Bu anlayışa göre mekân sosyal nesnelerin birbirine göre konumlanışıdır ve bir kez mekân yaratıldı mı artık onu oluşturan bileşenlere indirgenemez. Bunun yanında mekânın kendisini oluşturan nesneler üzerinde etki etme gücü vardır (Tümtaş, 2012). 
boyutlarında gizlidir. Bu bakış açısından, kamusal mekândan yani kent mekânından, söz ederken onun iletişimsel bir boyutunun olduğu da kabul edilmiş olunur (2012: 14). Kentsel mekân, kentin binalarla belirlenen, fakat binaların dışında kalan bölgeleri olarak tanımlanmaktadır (Çakmaklı, 1992: 7). Kentler bireylerin sosyalleştikleri, bir araya gelip etkinliklerde bulundukları mekânlardır. Kentler binalar ile donatılmıştır ve binalardan arda kalan tüm mekânsal boşluklar çeşitli amaçlara uygun biçimlerde kullanılan kentsel toplumsal mekânlar olarak düzenlenmiştir. Kentsel toplumsal mekânlar bireylerin en çok karşılaştıkları dolayısı ile de iletişim kurdukları mekânlardır.

Bookchin'e göre, kent "biyolojik bir yakınlığın toplumsal bir yakınlığa dönüşmesiyle ortaya çıkmış tarihi bir sahneydi" (1999: 18). Kentsel mekân fiziksel bir unsur olduğu kadar toplumsal bir unsurdur da. Urry (1999: 97) kaynakça da bu alıntı yok ise kentlerin toplumsal olarak üretilmiş olduklarının altını çizerek, yalın mekânların olmadığını bunun yerine "farklı türden mekânlar, mekânsal ilişkiler veya mekânsallaşma vardır" demiştir.

Bu bağlamda, tüm mekânlar üretilmiştir. Bu nedenle, kamusal kentsel mekânlar da üretilmiştir. Fırat'a (2002: 4) göre kentsel mekânda kamusal alana dönük okumalar yapma uğraşının temelinde Urry'nin sözünü ettiği bu yaratılmış mekânlar meselesi yatmaktadır. Yazara göre, bu üretilmiş mekânlar aynı zamanda üretilmiş kamusal alanlardır. Öztürk (2012: 18) ise mekânı verili mekânlar ve insan yapıntısı mekânlar olarak ikiye ayırır: ilkini Kant'ın değerlendirmesi ile ilişkilendirip doğanın ezelden beri kullandığı ve kullanmaya devam ettiği kendi dilinde yer olan potansiyel iletişim mekânı olarak açıklarken, ikincisini insanların belli bir amaç ve işlevleri doğrultusunda inşa ettiği yani ürettiği mekânlar olan fiili iletişim mekânları olarak tanımlamıştır. Bu bakış açısı ile baktığımızda kent mekânları insan yapıntısı mekânlardır. Çubuk'a (1991: 15) göre ise kentlerin yerleşme dokusunu meydana getiren, yapılaşmış ve yapılaşmamış olarak ayrılan alanlara kentsel mekân denir ve bu mekân genel olarak insanın yaşamı ile ilintili barınma, çalışma, eğlenme /dinlenme ve ulaşım gibi ana eylemleri geçirdikleri mekânların bütünüdür. Kentsel mekânlar, mülkiyet esasına göre özel alan ve kamusal alan olarak ayrılırken kullanım biçimleri üzerinden ele alındığında bu ikili ayrıma yarı özel ve yarı kamusal olarak iki yeni mekânsal tanım eklenebilir. Bir mekânın kamusal veya özel olduğunu belirleyen ölçüt mekânın kullanım hakkının kimde olduğuna, erişilebilir olup olmadığına, bakım ve sorumluluğunun kime ait olduğuna göre değişmektedir. Yani, özel alanı kamusal mekândan ayıran en belirgin ve en önemli özellik buranın kimin kullanımında olduğudur. Bir mekân herkesin erişimine açık ise orası kamusal mekân olmakta, kişisel mülkiyet hakkına sahip bireylerin olduğu bir mekân ise de özel alan olmaktadır. Kentsel mekânlar kullanım hakkı, sorumluluğu, bakım işleri ve denetim görevleri mülk sahibine ait olan ve bir kısmı da ticarete ayrılmış özel mekânlar ile tüm bireylerin kullanımına açık kentsel mekânlar olan kamusal olmak üzere iki temel sınıfa ayrılabilir. Bunlara ek olarak yarı özel mekânlar ise bir grubun ortaklaşa elinde tuttuğu ve ortak kullanılan mekânlardır. Yarı kamusal mekânlar ise toplumun kullanımına açık olan mekânlarıdır. Kullanıcılar belli zamanlarda belli kişilerden oluşur sorumlu kullanıcı ve kamudur. Yarı kamusal yada yarı özel alan olarak kabul edebileceğimiz kent mobilyaları, kent içindeki rekreasyon alanları, kent içerisinde başka amaçlar için üretilmiş ancak insanların bekleme, sigara içme, sohbet etme vs. gibi amaçlara yönelik kullandıkları kent "kıyıları", kent içerisinde maddi geçim kaynağı olarak kullanılan işporta tezgahları, evlerin ve dükkanların kapı önleridir. ${ }^{5}$ Tarihte bilinen ilk kent mobilyaları Antik Yunan'da kullanılan mil taşları, at bağlama 
kazıkları ve yalaklardır6 (Keskin, 2008). Sennett Ten ve Taş: Batı Uygarlığında Beden ve Şehir (2011: 44) adlı eserinde Antik Yunan'da stoa denilen bir buluşma mekânından söz eder ve bu mekânın agora meydanının hemen yanında insanların başlarını sokacakları bir yer ve buluşma mekânı olarak tanımlar. Bunun yanında kalabalıkların stoadan tüm agorayı seyredebildikleri bir yer olduğundan söz eder. Stoaları ilk kent mobilyaları kapsamına almak mümkündür. Günümüz için ise otobüs durakları, çöp kutuları, anıtlar, sokak lambaları, reklam-ilan panoları, büfeler, merdivenler, banklar, çeşmeler birer kent mobilyalarıdır. Kent mobilyalarının dizaynı ve yerleştirilme biçimleri bir kentin kimliğini oluşturmada büyük öneme sahiptir. Kent mobilyalarının yerleştiriliş biçimleri bir kentin tasvir ederken "karmașık" veya "huzurlu" sıfatlar kullanmanın gibi bulunmanın temelini oluştur. Kent mobilyalarının yerleşim -düzenlerinin sağlanmasına şehir planlamacılığı denir. Ürün tasarımı ve şehir planlama gibi kavramaların yan yana kullanıldığı ve birleşerek ortak bir nokta oluşturdukları alan kent mobilyalarıdır (Güneş, 2005: 3-4). Kentsel mekânlar içerisinde kullanılan, insanların yaşamlarını kolaylaştırmayı ve güvenliği sağlayan ve toplumsal yaşam gerekliliklerine katkıda bulunan her türlü araca kent mobilyaları denmektedir. Kent mobilyası kentsel tasarımda bilgi-iletişim panosundan çöp kutusuna, heykelleri, merdivenleri, çeşmeleri ve telefon kulübeleri gibi objeleri içerir. Kent mobilyaları herkese açık ve kamunun sorumluluğunda olan yapılanmış veya yapılanmamış kentsel kamusal alanlarda, genellikle mekânı tamamlayan ve tanımlayan bir nitelik içerir. Koruma amaçlı, eğlenme amaçlı, ticari amaçılı olarak çeşitlilik gösterir (Öztürk, 1994: 69).

Bir mekânda mobilyaların varlığı çeşitli ön varsayımları da beraberinde getirmektedir. Örneğin, bir kentte veyahut ta evde mobilya kullanılması o mekânlarda yaşayan bireylerin olduğu anlamına gelmektedir. Çağdaş iletişim kuramcıları, kentin onun içerisinde yaşayan ve algılayan bireyler üzerinde etkin mesajlar içerdiğini belirtmişlerdir. Kişilerin kent içerisinde gösterdikleri davranışlar mekânı ve çevre düzenini algılamaları ile şekillenmektedir. Çalışmanın ana konusunu oluşturan kent mobilyaları bu anlamda kişilerin iletişim coğrafyalarını oluşturmalarına olanak sağlamaktadır. Kent mobilyaları birer kullanım nesnesi olarak her şeyden önce kendisinin ontolojik nedeni olan işlevine yönelik bir bildiri içerir. Kent mobilyaları bir anlam aktarma, anlamaya konu olma, bilgi aktarma ve bir bildiri taşıyanı olma gibi iletişimsel işlevler yüklenen kısa ömürlü sistemlerdir (Bayrakçı, 1991: 75-76, Bayazıt, 2003: 34). Bu sayede kent mobilyaları kent kimliğini oluşturmada büyük rol oynarken aynı zamanda iletişimin de mekânı olurlar. Çalışma kapsamında kent mobilyalarından biri olan bankların, Woody Allen sinemasında iletişim mekânı olarak kullanımı irdelenecektir.

\section{Woody Allen Filmlerinde İletișim Mekânı Olarak Bankların Kullanımı}

Woody Allen, sinemada kent mekânını oldukça etkin olarak kullanan yönetmenlerden biridir. Dolayısı ile kent mekânının tüm olanaklarını sinemasına yansıtmıştır. Bu çalışma için Allen'in seçilmesinin kent mekânının aktif kullanmasının yanında bir diğer sebebi senaryosunu kendi yazdığı filmleri yönetmesidir. Bu sayede kentin sinemada olan görünürlüğünün hem hikayesini hem de nasıl görüntüleneceğinin kararını sadece Allen vermektedir. Bu da onun filmlerinin verimli ve tutarlı bir çözümleme alanı haline getirmektedir.

On dokuzuncu yüzyılın sonundan bu yana sinema ve kent birbiri ile ayrılmaz bir ilişki 
içinde olmuştur. 1895 yılında Lumiere Kardeşler'in Paris'i mekân olarak kullanması ile başlayan sinemanın hikayesi kent ile de ilişkisinin başladığı bir dönem olmuştur (Shiel,2001: 1). Öztürk'e (2002: 14) göre Lumiere'ler ve Méliès'den itibaren kent sinemanın dokusunu oluşturmaya başlamıştır. Bir başka görüşe göre de sinema ve kent ilişkisi sesli filmler ile birlikte günümüze kadar daha derinleşerek devam etmiştir. New York ve Los Angeles gibi ABD kentleri birçok türde film için mekân olmuștur. Örneğin New York'un Manhattan bölgesi, Woody Allen'in birçok filminde önemli bir rol oynamıştır (Ulusay ve Kılıçbay, 2009: 20). Sinema ile birlikte insanlar kentte, gündelik yaşamda fark edemeyecekleri ayrıntıların ayırdına varmaya başlamışlardır (Clarke, 1997:2).

Woody Allen yukarıda da belirtildiği gibi kent mekânını dolayısı ile de kent mekânının ona sunduğu tüm olanakları sinemasında kullanmıştır. Bu olanakların içinde kent mobilyaları da önemli bir yer tutmaktadır. Allen kimi zaman kent mobilyalarını anlatının ana mekânı olarak kurgularken, kimi zaman da bunları hikayelerinin fonunda gündelik hayatın önemli bir parçası olarak sunar. Örneğin filmin ana karakteri koşarak onlarca bankın içerisinden geçer. İçerisinden geçtiği bu banklar insanların gazete, kitap okudukları, arkadaşların ve aşıkların sohbet ettikleri, dinlendikleri, atıştırdıkları vb. gündelik yaşam etkinlikleri gerçekleştirdikleri mekânlar olarak görünmektedir. Tüm bu karelerin hiçbirinde bankların kullanıcısı ana hikayenin asıl kahramanları değildirler. Daha çok bir kent fonu veyahut ta kent örüntüsü olarak belirirler. Buna karşın Allen'in ana karakterlerini buluşturduğu, yalnız bıraktığı, aşık ettiği, cinayet planları yaptırdığı, sırlarını açıkladığı, hayatlarını dönüştürecek önemli bilgileri burada elde etmelerini sağladığı kent mobilyaları da vardır. Bir sonraki başlıkta Allen'in bankları nasıl bir iletişim mekânı olarak kullandığı, bu iletişim mekânlarının filmin anlatısı içerisinde ne gibi anlamlara geldiği üzerinde durulacaktır.

Kent yaşamı hızlı, akışkan ve süreklilik içermektedir ve bu özellikleri, içinde yaşayan bireylerin kimi zaman kendilerini bu akışın içerisinden geriye çekme gereksinimleri yaratır. Sennett $(2011,303-304)$ hıza karşı konforun zıtığını anlatırken konforu pasiflikle ilişkilendirmiştir. Ona göre, 19. Yüzyıl'da ortaya çıkan rahatık ve konfor arayışı önce bedensel bitkinlikten kurtulma ve dinlenmeye aracı eden mekânlar arayışı olarak algılansa da sonraları bu mekânlar rahatlama mekânlarına dönüştüğünü ifade etmiştir. Bireyin dinlenip rahatlaması için diğer insanlardan uzaklaştığı ve dolayısı ile yalıızlaştığı sonucuna varmıştır.

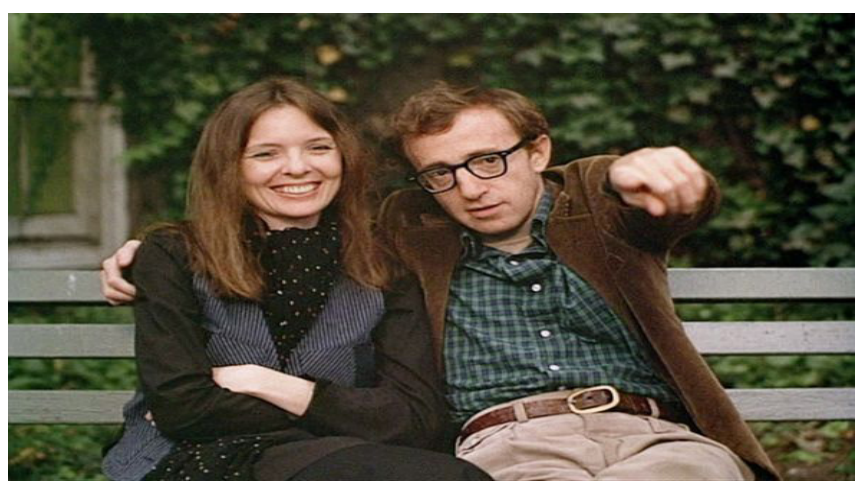

Resim.1. Annie Hall (1977) 


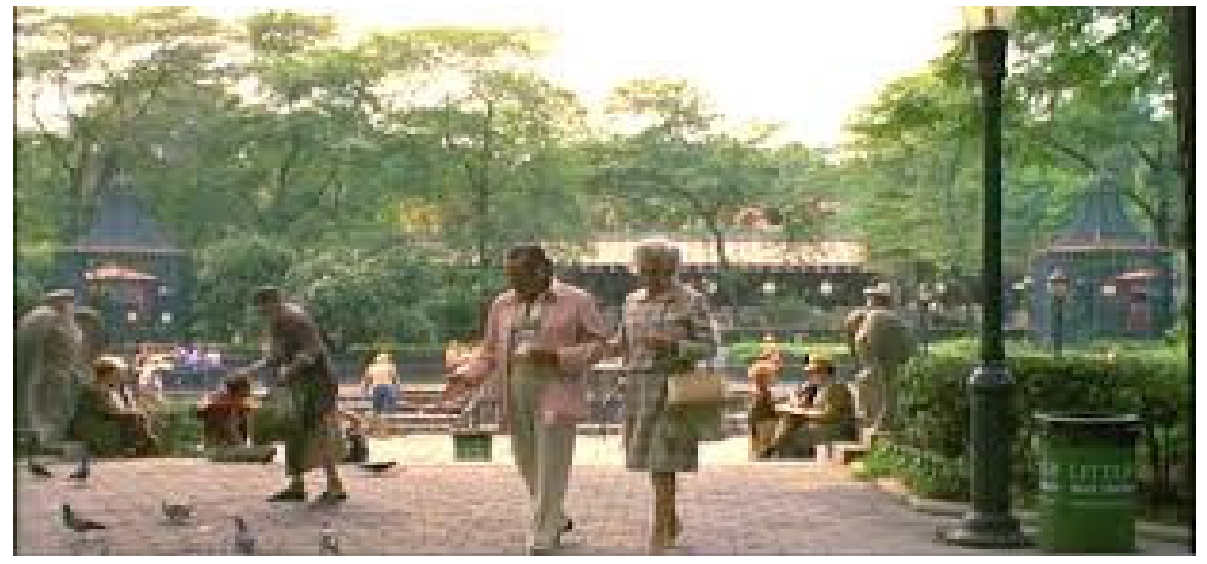

Resim.2. Annie Hall (1977)

Bireyler kent içerisinde yukarıda da sözünü ettiğimiz hız ve hareketten koparak "dinlenmeyi" seçmekte ve bu eylemleri sonucunda içinden akıp gittikleri kentsel mekânı artık seyirlik bir nesne olarak görmeye başlamakta, Sennett'in (2011: 304) tabiriyle pasif birer özneye dönüşmektedirler. Ancak kent mobilyaları aynı zamanda kentsel bir karşılaşma mekânı olarak da işlev görmektedir. Örneğin kentsel bir mekânda bir bankı kullanan kişi yanına oturacak kişi ile iletişime girme potansiyeli ile karşı karşıya olacaktır. "Hız"dan koparak duraklayan birey bir diğer kişiyle olan iletişim sürecine olanak sağlayacaktır. Bu nedenle de bankları konu eden bu çalışma onların bu potansiyellerinden yola çıkmaktadır.

Sennett'in (2011: 304) pasifleşme dediği olgu Woddy Allen'in Annie Hall (1977) adlı filminde somutlaşmıştır. Resim 1'de görülen karede Annie Hall ve sevgilisi Alvy Singer'ın bir banka oturup kentin o banktan görülen manzarasını (Resim 2) birlikte analiz etmektedirler. Böylece kentin akışından çıkıp ‘kıyıdan' kenti analiz etme durumuna geçmişlerdir. Sennett'in pasifleşmesi, aslında düşünsel bir sürece evrilerek, kenti gözlemleyerek yorumlama halini almıştır. Annie ve Alvy'nin arasında geçen diyalog aşağıdaki gibidir;

"Şu adama bak Bay Miami Plajı, pembeler giymiş, iskambil oyunu partisinden dönüyor ve üçüncü olmuş, Şunlara bak Neşe içindeler. Ateş adasından geliyorlar, İlişkilerine romantik bir şans veriyorlar.

- $\quad$ İtalyan değil mi o?

- $\quad$ Mafya o, kumaş işinde ya da çimento müteahhidi. Bu da Truman Capote Benzerleri Yarışması'nın galibi”

Annie ve Alvy, bu şekilde orada bulunan insanlar hakkında tahminler yürütüp onların hakkında hikayeler uydurmaktadırlar. Bu sayede de bir kent mobilyasını kente doğru açımlanan bir gözlemleme mekânına dönüştürmüş olmaktadırlar. Bireylerin mekânı kullanım biçimleri onların hem mekân ile hem de birbirleriyle ilişikleri hususunda birtakım bilgiler verir. Bedenlerin söz konusu bilgiler için verimli kaynaklar olduğunu

7 Annie Hall (1977): Yönetmen: Woody Allen, Senarist: Woody Allen, Marshall Brickman Oyuncular: Woody Allen, Diane Keaton,Tony Roberts, Carol Kane, Paul Simon Süre: 93.dk,Ülke: ABD, Orijinal Dil: İngilizce 
söylemek mümkündür. Sözü geçen sahne, bedeni merkeze alarak değerlendiğinde her iki karakterin aralarındaki duygusal ilişkinin etkisiyle birbirlerine oldukça yakın oturdukları görülmektedir. Filmin ana hikayesinin bu iki karakterin arasında gelişen duygusal ilişki üzerinden geliştiği göz önünde bulundurulduğunda, bedensel duruşlar duygusal ilişkinin atmosferini seyirciye ulaştırmada çok etkili olmaktadır. Karakterlerin yan yana yürürken durarak banka oturmaları, kamusal alandan koparak kamusal alan içerisine bir özel alan yaratmalarına olanak sağlamışlardır. Yeni yarattıkları bu özel alanı korumak adına da bankın tam ortasına konumlanarak yanlarına bir başkasının oturmasını intimal dışı bırakmışlardır. Bu durum bankı kullanım süresi boyunca onlara özgü kılmıştır.

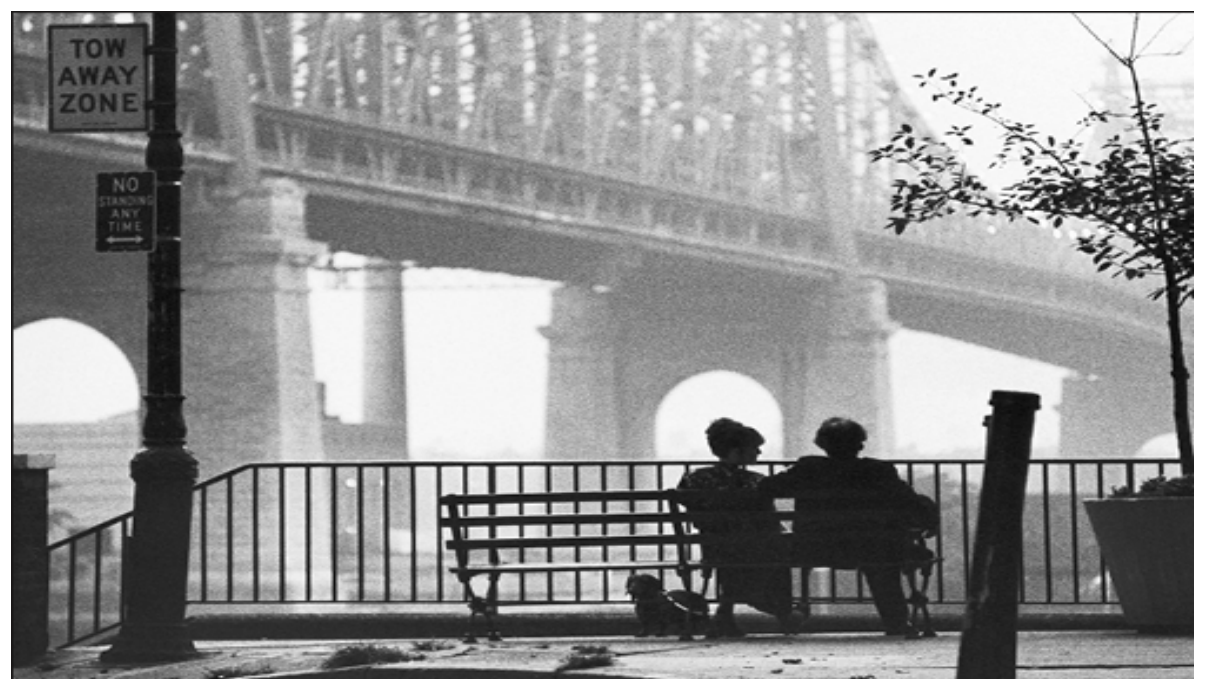

Resim.3. Manhattan (1979)

Buna benzer bir kare Allen'in Resim 3'de görülen Manhattan (1979) filminde de farklı bir boyutta ortaya çıkmaktadır. Bu filmde yakınlaşama sürecinde olup ancak henüz aşk yaşamaya başlamamış olan Isaac ve Marry kenti bir manzara, seyirlik bir nesne olarak görebilecekleri bir banktan izledikleri manzara aracılığı ile kente methiyeler düzerler. Aralarında geçen diyalog aşağıdaki gibidir.

“-Dışarısı ne kadar güzel, değil mi?

- Işıklar yanınca gerçekten çok güzel oluyor.

- Farkındayım bayılıyorum buna,

- Tanrım... Kim ne derse desin burası harika bir şehir... Öylesine muhteşem ki !

- Evet"

Burada da kentin biçimsel görünümü hakkında kimi yargılarından söz etmektedirler. Böylece kent artık o an, içinde "yaşadıkları yer" olmanın yanında seyirlik bir objeye dönüşmektedir. Bu dönüşümü gerçekleştirmenin söz konusu sahne için temel koşulu ancak bir banka oturmaları sayesinde gerçekleşir. Çünkü bu şekilde şehrin içinde onun 
hızına kapılarak gitmek yerine onu izlenebilir bir manzara olarak algılayabilmişlerdir. Karakterlerin mekânla ilişkileri bedenleri üzerinden değerlendirdiğinde, erkek karakterin bir kolunu bankın arka kısmına yasladığı ve kadına göre daha öne kayarak oturduğu gözlenmektedir. Kadının daha az yer kaplamasının yanında yine de rahat olduğu imajı sağlanmıştır. Her iki karakterin de sırtı oradan geçmesi muhtemel olan insanlara dönük olduğundan, kendilerini kamusal alandan daha soyutlayarak, oturdukları bankı özel alana dönüştürmelerinin olanağı sağlanmıştır.

\section{a. “Așk” Mekânı Olarak Banklar}

Woody Allen'ın filmlerinde bankların kullanım amaçlarından biri, karakterlerin aralarındaki duygusal ilişki hakkında konuştukları, belli kararları veya fikirleri birbirlerine ilettikleri bir filmsel mekânı oluşturmaktır.

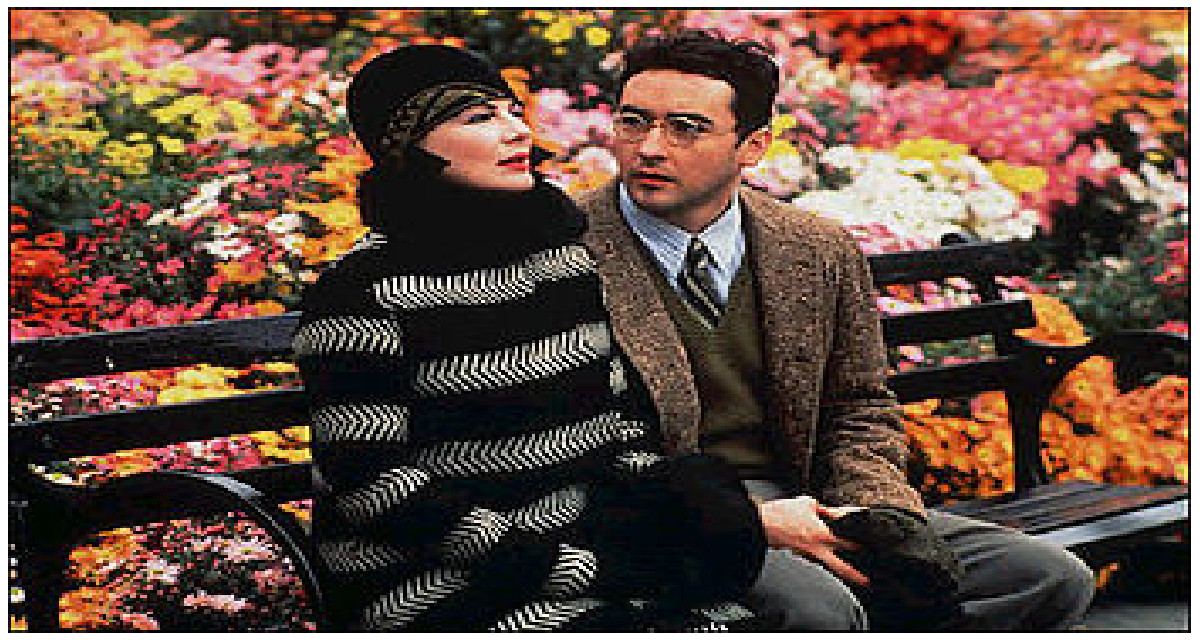

Resim.4. Brodway Üzerine Kurşunlar ( 1994)

Örneğin Resim 4'de görünen ve Brodway Üzerine Kurşunlar (1994) ${ }^{9}$ adlı filmden karede, aslında platonik bir aşkın konu olduğu bir mekân görülmektedir. Oyun yazarı olan David Shayne başrol oyuncusu Helen Sinclair'a aşık olmuştur ancak bu aşkına bir karşılık alamamakla beraber keskin bir reddediliş de yaşamamıştır. Bu karede David'in Helen'i ikna etmek ve ona aşkını anlatmak için mekân olarak bir bank seçtiği görülmektedir. Söz konusu kare değerlendirildiğinde, karakterlerin filmin anlatısındaki konumlarını destekleyecek bir biçimde kadının oturuş biçimi daha kendine güvenli, tavizsiz iken erkek daha düşük omuzlu ve daha pasif bir görüntü sergilemektedir. Bu kent mobilyasında kişiler aslında kent ile olan bağlarını kesmişler ve tamamen kendileri arasındaki iletişime yönelmişlerdir. Bankın büyük bir kısmını kaplamaktadırlar.

Bu sayede bank, kamuya açık olma özelliğini bir süreliğine David ve Helen'e devretmiştir. İki kişinin duygusal yoğunluklarını konu edinen konuşmalar, normal

9 Brodway Üzerine Kurşunlar(1994) Orijinal Adı: Bullet Overs Brodway Yönetmen: Woody Allen, Senarist: Woody Allen,_Douglas McGrath Oyuncular John Cusack, Dianne Wiest, Jennifer Tilly, Chazz Palminteri, Joe Viterelli, Jack Warden Süre: 98 dk,Ülke: ABD Orijinal Dil: İngilizce 
şartlarda özel alana aittir. Ancak kentin içerisinde banklar sayesinde özel alana ait olan davranışlar kamusal alanın içine taşınmış, sınırlar silikleşmiştir.

Birbirlerine duygusal ilgi besleyen bireylerin buluştuğu bir başka bank Kim Kiminle Nerede? (2009) ${ }^{10}$ adlı filminde görülmektedir.

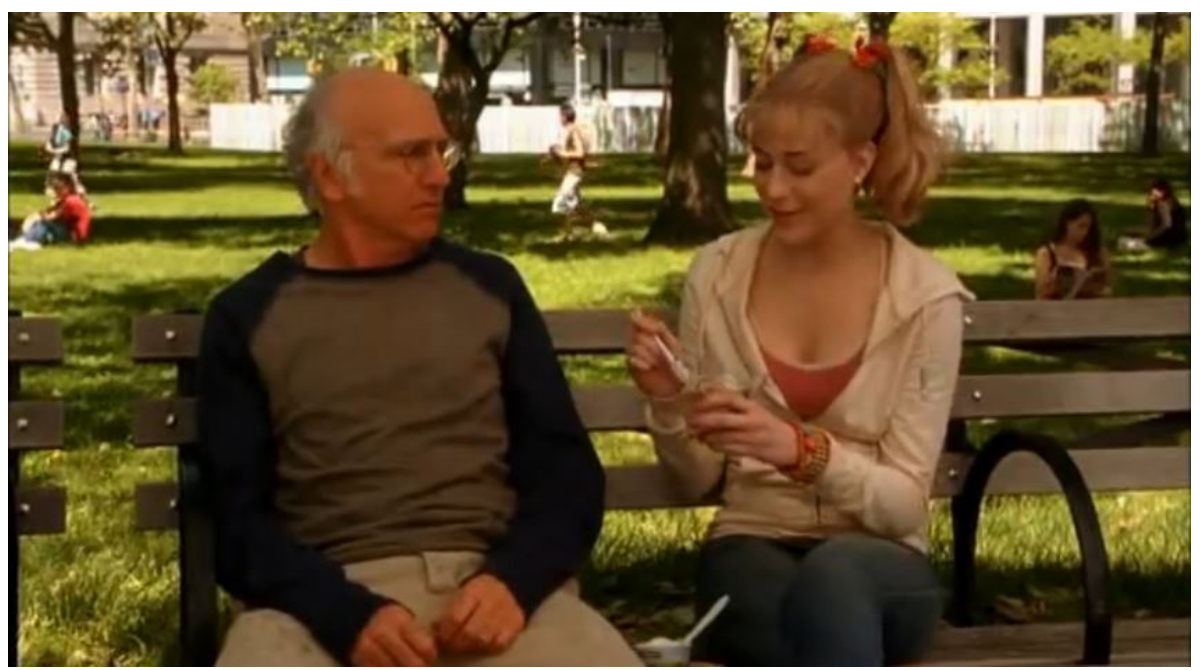

Resim.5. Kim Kiminle Nerede (2009)

Evli bir çift olan Boris ve Melodie bir bankta oturmakta ve bir şeyler yiyerek gündelik konuşmalarını gerçekleştirmektedirler. Evlerinde konuşabilmeleri mümkünken bu konuşmaların bir kent mobilyasında gerçekleşmesini tercih etmişlerdir. Oturma biçimleri onların iletişimlerinin nasıl olduğuna dair ipuçları içermektedir. Erkek, sırtını banka tamamen dayamış bacakları kadınınkine nazaran daha açık ve bedeni doğrudan karşıya bakmaktayken, kadın bacak bacak üzerine atarak daha az yer kaplamış bunun yanında da sırtını tam olarak banka dayayamamış yönünü erkeğe doğru çevirmiştir. Kadın için iletişimin asıl kaynağı ve yönü erkek iken erkeğin durumu bir başka kişi ile iletişime geçmeye açıktır. Bu durumda bank üzerinde gerçekleşen kişiler arası iletişim süreci bank aracılığıyla kamusal olan parkın içerisinde özel alana yaratmış ve özel alan, kamusal alan arasında bir geçirgenlik açığa çıkarmıştır.

Duygusal ilişki bağları olan bireylerin sohbet ettiği, buluştuğu ve iletişim kurduğu bir mekân olarak kent mobilyalarına Allen'in sinemasından verebilecek bir başka örnek Uzun Boylu Esmer Adam (2010) ${ }^{11}$ filminde yasak aşk yaşamaya başlamak üzere olan Roy ve Dia 'nın oturduğu banktır.

10 Kim Kiminle Nerede (2009) Orijinal adı: Whatever Works Yönetmen: Woody Allen, Senarist: Woody Allen Oyuncular: Larry David, Adam Brooks, Lyle Kanouse,Michael McKean,Clifford Lee Dickson, Süre: 92 dk., Ülke ABD: Orijinal Dil: İngilizce

11 Uzun Boylu Esmer Adam (2010) Orijinal İsmi: You Will Meet a Tall Dark Stranger Yönetmen: Woody Allen Senarist: Woody Allen Oyuncular: Anthony Hopkins, Antonio Banderas, Naomi Watts, Freida Pinto, Josh Brolin, Süre: 98 dk Ülke: ABD Orijinal Dil: İngilzce 


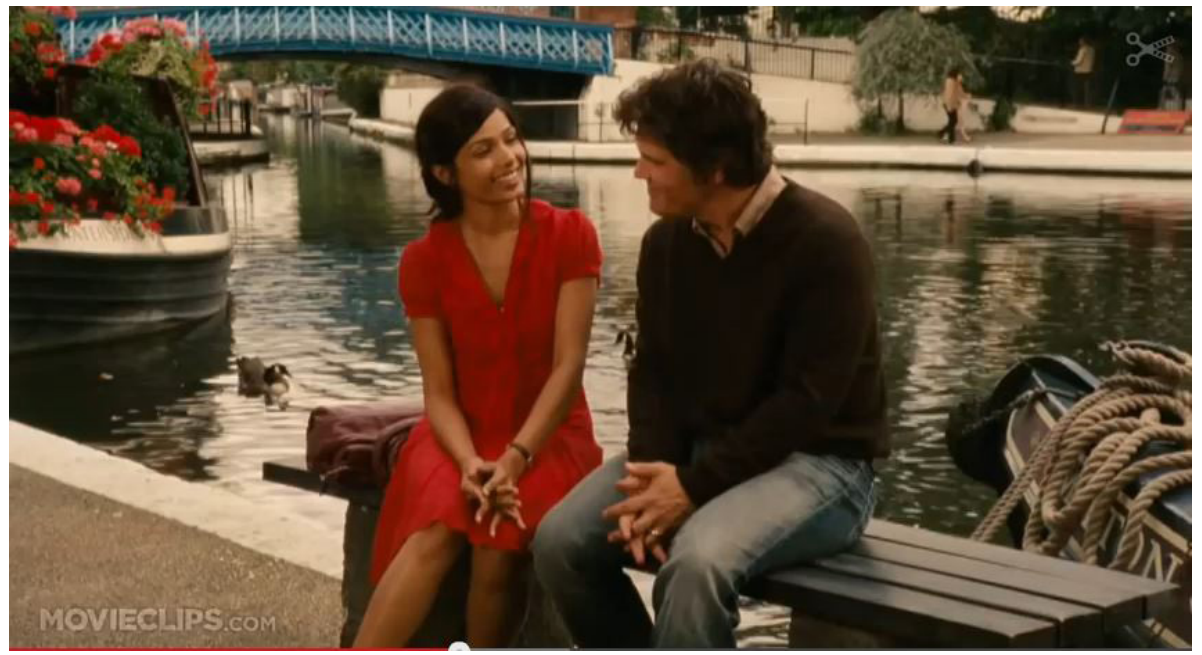

Resim.6. Uzun Boylu Esmer Adam (2010)

Her ikisi de başka kişilerle aşk yaşayan bu iki karakter birbirleri ile ilk etapta kentsel mekânlarda buluşurlar. Bu karede de (Resim.6) bir kent mobilyası onların sohbetlerine mekân olmuştur. Karakterlerin iletişim biçimlerini yansıtan oturma biçimleri irdelendiğinde tıpkı Kim Kiminle Nerede (2009) filminde olduğu gibi erkeğin vücudu doğrudan karşıya bakmaktayken kadın yönünü erkeğe çevirmiştir. Her ikisi de belki de yasak bir ilişkinin eşiğinde olmaktan veya birbirilerine henüz nasıl davranmaları gerektiğini bilmediklerinden ellerini önlerinde kavuşturmuşlardır. Bu da onların tam olarak özgüven ile yerleşemediklerinin bir sonucu olarak algılanabilir. Ancak kadın çantasını hemen arkasına bırakarak bu mekâna bir özel alan olma durumu kazandırmıştır.

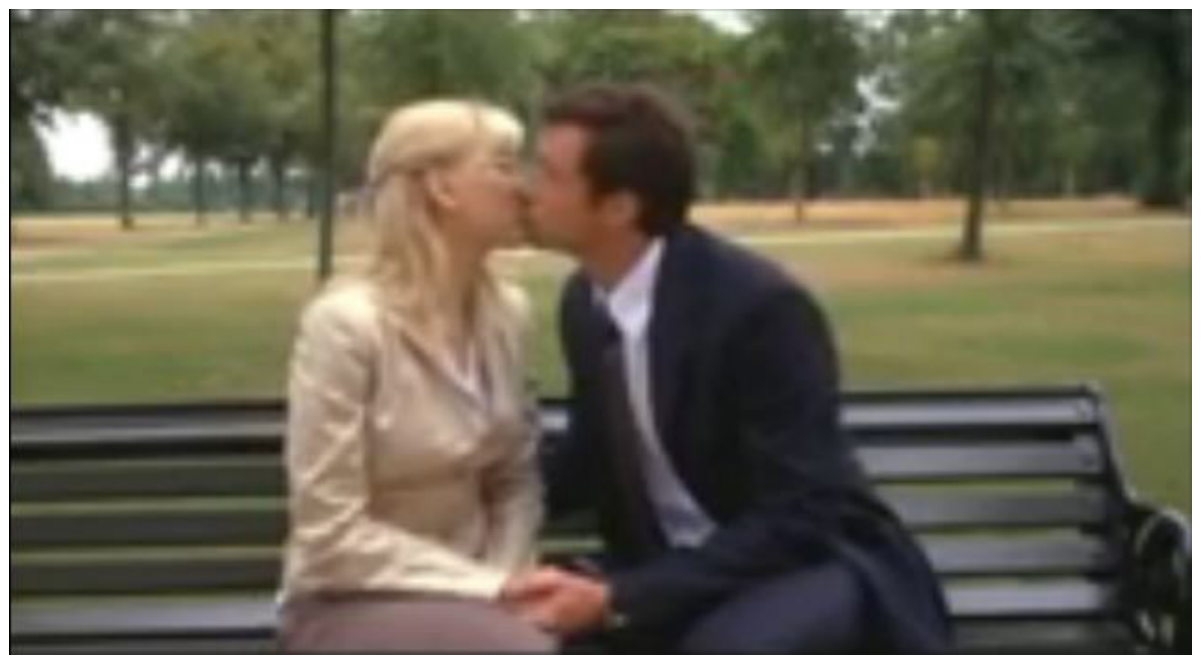

Resim.7. Scoop (2006) 
Aşıklar için mekân olan bir diğer kent mobilyası Allen'ın 2006 yapımı Scoop ${ }^{12}$ adlı filminde görülmektedir. Sondra Pransky ve Peter Lyman karakterlerinin oturduğu bu kent mobilyası, aslında özel alana ait olan bir eylemin, öpüşmenin, kamusal alana içerisine taşınmasına olanak veren bir geçiş mekânı olmuştur. Böylece söz konusu bank bir yandan özel alana ait kılınan aşkın kamusal bir mekânda tezahür etmesinin aracısı olurken, diğer yandan da, kamusal alan içerisinde bir özel alan yaratmanın mekânı olmuştur.

Allen'in Paris'te Bir Gece Yarısı (2011) ${ }^{13}$ adlı filminde ise bir bankta aralarında duygusal bir ilişki bulunmayan bir kadın ve erkek bir bankta oturmaktadırlar. Kadın karakter bir müze rehberidir ve filmin başkahramanı Gil Pender'in isteği üzerine bir kitabı tercüme etmektedir. Bu kitabın tercümesi film anlatısında kilit bir öneme sahiptir. Allen, Gil Pender'in başına gelenlerin esas sebebi hakkındaki oldukça önemli bilgilerin açığa çıktığı bu sahnede, mekân olarak bir bank tercih etmiştir.

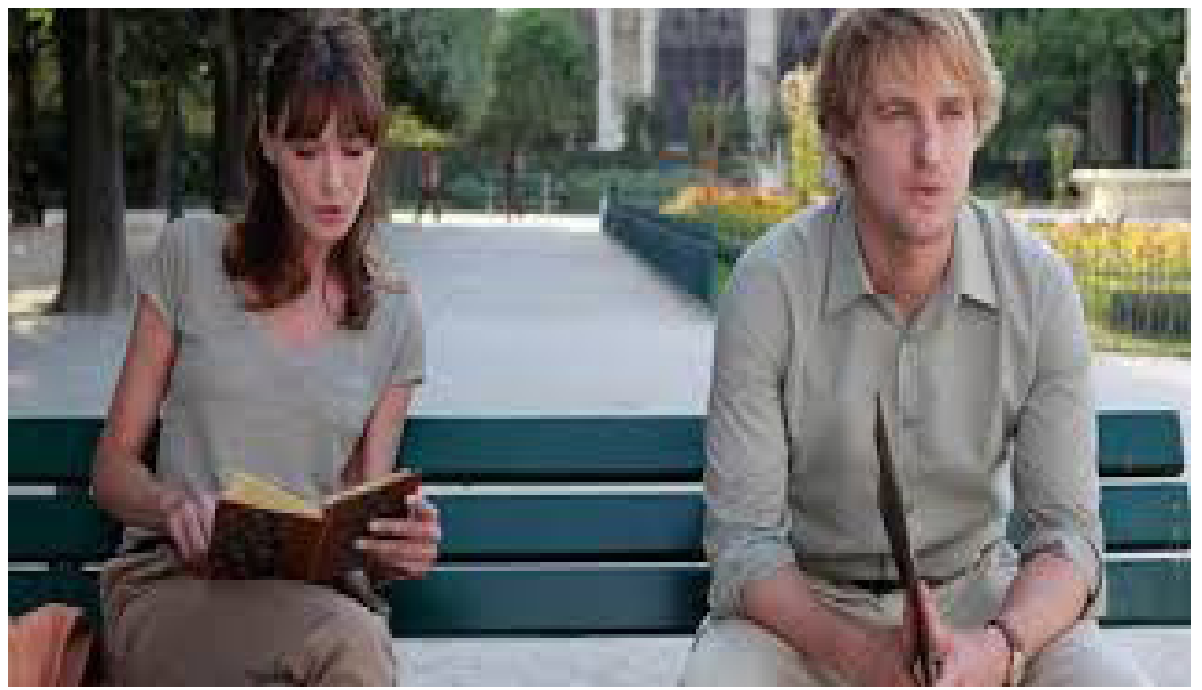

Resim.8. Paris'te Bir Gece Yarısı (2011)

Kadın ve erkeğin oturma biçimlerine bakıldığında kadın bacak bacak üzerine atmış daha az yer kaplamaktadır. Erkek ise ellerini dizlerinin üzerine koymuş bacakları daha açık ve dolayısı ile de daha fazla yer kaplamaktadır. Kadın yine çantasını yanına bırakmış bu mekânı "kendinin" yapmak için bir girişimde bulunmuştur.

\section{b. Erkelerin Duraklama Mekânı Olarak Banklar}

Buraya kadar Allen'in filmlerinde bir kadın ve bir erkeğin birlikte kullandığı kent

12 Scoop (2006) Yönetmen: Woody Allen, Senarist: Woody Allen Oyuncular: Anthony Hopkins, Antonio Banderas, Naomi Watts, Freida Pinto, Josh Brolin Woody Allen, Süre: $98 \mathrm{dk}$, Ülke: ABD-İngiltere Orijinal Dil: İngilizce

13 Paris'te Bir Gece Yarısı (2011) Orijinal Adı: Midnight In Paris Yönetmen: Woody Allen, Senarist: Woody Allen Oyuncular: Owen Wilson, Rachel McAdams, Michael Sheen, Kathy Bates, Marion Cotillard Süre: 94dk.,Ülke: ABD-Fransa -İspanya Orijinal Dil: İngilizce 
mobilyaları yani banklar ele alınmıştır. Ancak Allen'in sinemasında sadece erkeklerin kullandığı banklara da yer verilmiştir. Örneğin Yok Ya (2003) $)^{14}$ filminde David Dobel ve Jerry Folk arasında geçen iletişimin çok büyük bir kısmı kent mobilyalarında gerçekleşmektedir.

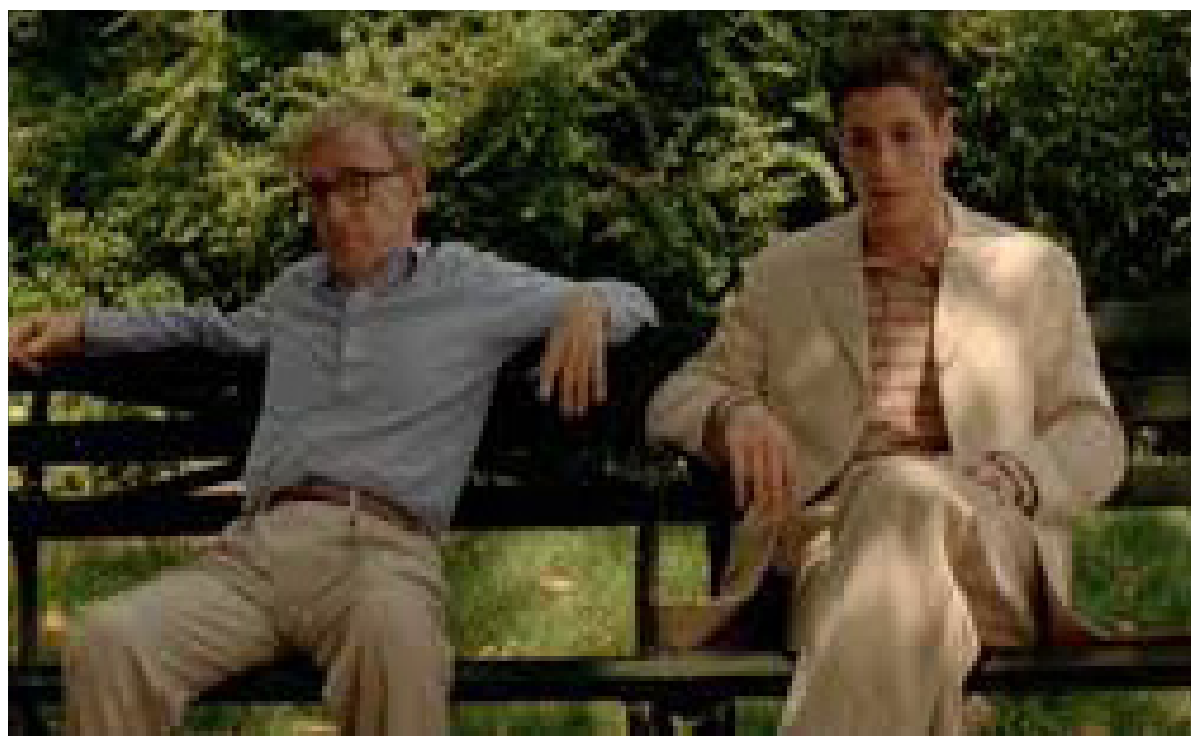

Resim.9. Yok Ya ( 2003)

David Dobel, Jerry Folk için hakkında bilgiler edindiği, tecrübelerini dinlediği bir öğretmendir. Jerry Folk'un hayatında çok önemli dönüm noktaları içeren bu ilişkinin büyük bir çoğunluğu kent mobilyalarında geçmektedir ve çok sıradan bir tercihle bir restoranda veya bir kafede konuşabilecekleri konuları konuşmak için filmde kent mobilyaları seçilmiştir. Karakterlerin beden duruşları değerlendirildiğinde güçlü ve baskın karakter rolünde olan David Dobel'in bedensel duruşu şimdiye dek incelenen karakterlerden bariz bir şekilde ayrılmaktadır. İki kolunu arkaya yaslamış ve yana doğru açmıştır. Bacakları ise oldukça fazla yer kaplamasına neden olacak kadar açıktır ve sonsuz bir özgüveni varmışçasına oturmaktadır. Jerry Folk ise Dobel'in aksine daha derli topludur. Çalışma boyunca Brodway Üzerine Kurşunlar üzerine gerçekleştirilen inceleme dışarda tutulduğunda kadın karakterlere özgü değerlendirilen oturma stili burada bir erkekte görülmektedir.

Allen'ın yine erkek karakterlerin buluşma noktası olarak kent mobilyasını uygun gördüğü bir diğer filmi olan Cassandra'nın Rüyası (2007) ${ }^{15}$ adlı filmde Terry, Howard ve Lan bir bankta bir kişinin öldürülmesi planının ardından herkesten gizli gerçekleştirdikleri konuşmaları için yine bir kent mobilyasını, bir bankı tercih etmişlerdir.

14 Yok Ya (2003) Orijinal Adı: Anything Else Yönetmen: Woody Allen, Senarist: Woody Allen Oyuncular: Jason Biggs, Woody Allen, Christina Ricci, Danny DeVito, Jimmy Fallon Süre: 108 dk, Ülke: ABD, Fransa, Hollanda, İngiltere Orijinal Dil: İngilizce

15 Cassandra'nın Rüyası(2007) Orijinal Adı: Cassandra's Dream Yönetmen: Woody Allen, Senarist: Woody Allen Oyuncular: Colin Farrell, Ewan McGregor, Hayley Atwell, Tom Wilkinson, Sally Hawkins, Süre: 108 dk. Ülke: ABD, İngiltere, Fransa Orijinal Dil: İngilizce 


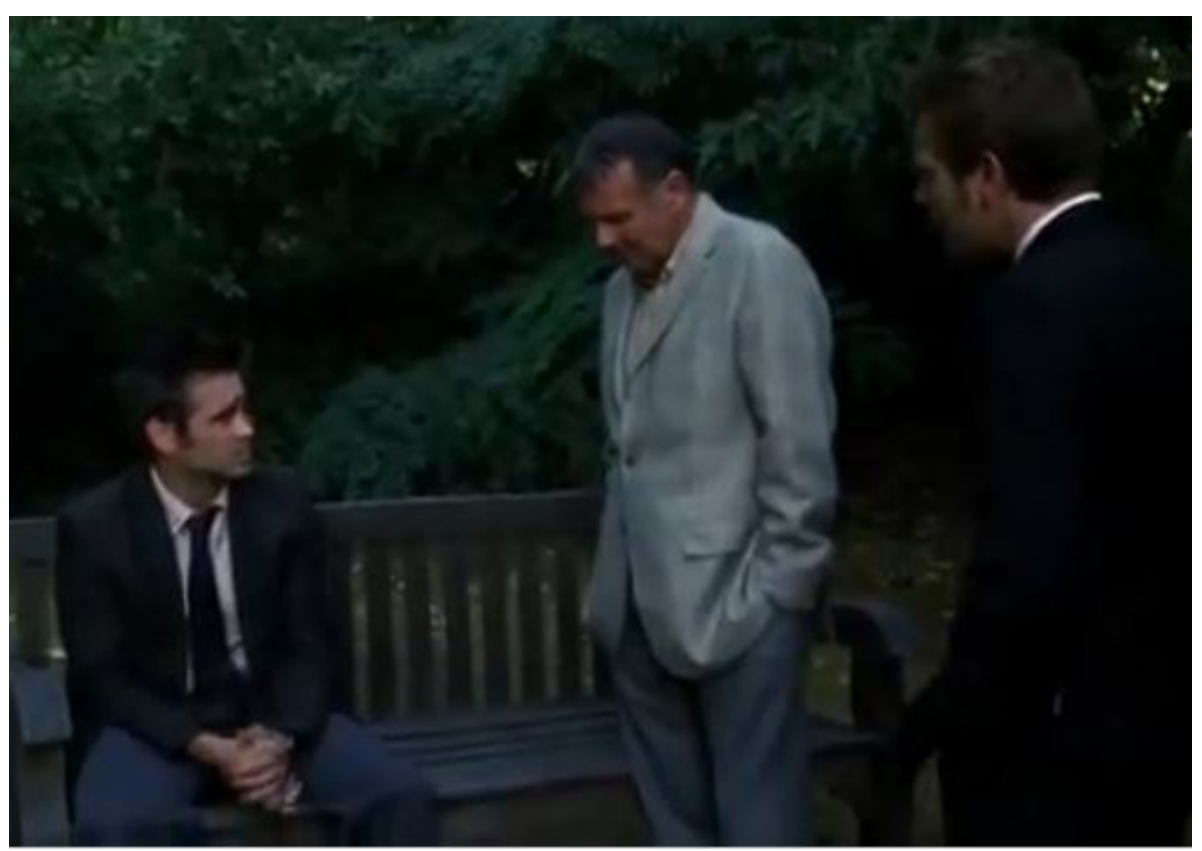

Resim.10. Cassandra'nın Rüyası (2007)

Resim 10'da da görüldüğü gibi bir araya gelen üç erkek oldukça gizli kalması gereken bir konuyu bir bankta konuşmaktadır. Ancak buradaki kent mobilyasının bir parkta değil büyükçe bir bahçenin içerisinde olduğunun da altını çizmek gerekmektedir. Bu yönüyle kent mobilyası zaten kamusal alan içerisinde değildir. Ancak evlerin bahçeleri de kamusal alan ve özel alanın geçişgenliğinde yarı kamusal alandır. Dolayısı ile buradaki kent mobilyasının kullanımı da kamusal alanda bir özel alan yaratma aracı olarak görmek mümkündür. Bu filmde kent mobilyasının kullanım süresi oldukça kısadır.

Karakterlerin bedenlerinin duruşları irdelendiğinde oturan karakterin elleri yine birbiri ile buluşmuştur ve dizlerinin üzerinde durmaktadır. Bu karakter kendisinin yapmış oldukları öldürme planından ve sonuçlarından huzursuzluk duyması dolayısıyla diğer iki karaktere nazaran oldukça zayıf bir ruh haline sahiptir. Kesit olarak aldığımız bu bank sahnesinde, cinayeti diğerlerine anlatmaya çalışmaktadır. Görülebileceği gibi kent mobilyası yine güçlü ve zayıf karakterin karşılaştığı bir mekân olmuştur.

Bankların erkeklerin buluşma noktası olarak kullanıldığı bir diğer Allen filmi ise 2013 yılında çektiği Roma'ya Sevgilerle ${ }^{16}$ adlı filmidir.

16 Roma'ya Sevgilerle (2013 ) Orijinal Adı: To Rome With Love Yönetmen: Woody Allen, Senarist: Woody Allen Oyuncular: Penélope Cruz, Ellen Page, Roberto Benigni, Jesse Eisenberg, Alec Baldwin, Süre: 112 dk,Ülke: ABD, İtalya, İspanya Orijinal Dil: İngilizce 


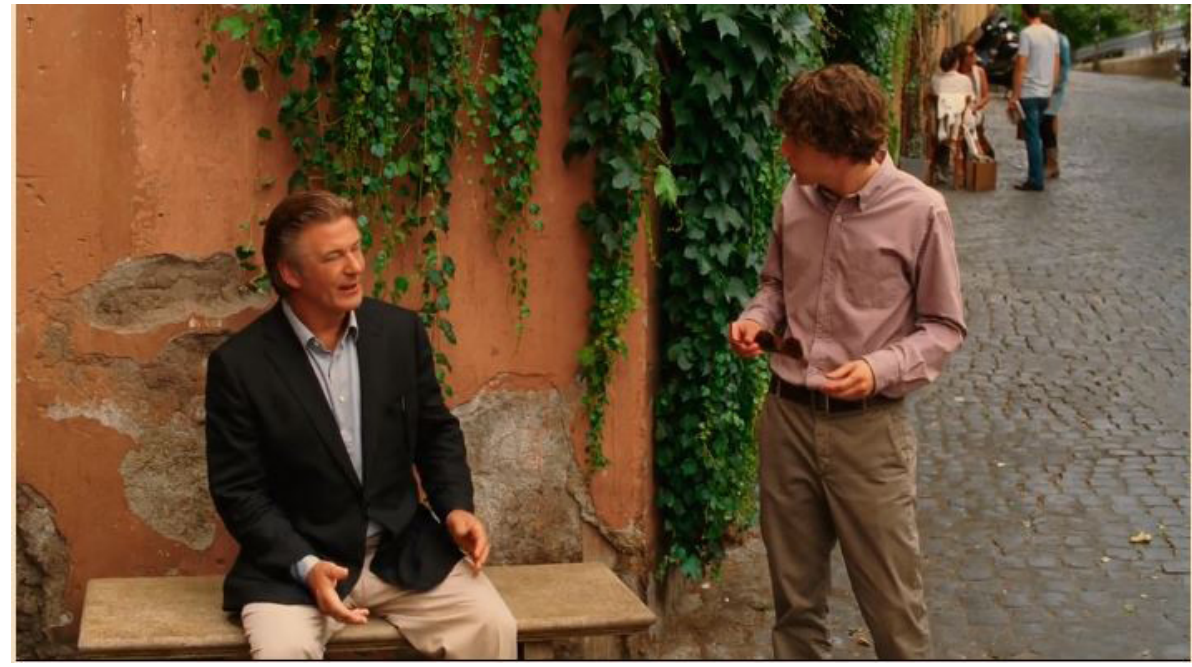

Resim.11. Roma'ya Sevgilerle (2012)

Resim 11'de de görüldüğü gibi bank bu filmde de bir karşılaşma noktası olmuştur. Bank John ve Jack'in karşılaşmalarına olanak vermiştir. Kent mobilyasının buradaki konumu, iki sokağın kesiştiği bir nokta olmasından ötürü zaten karşılaşmaları sağlaması konusunda elverişlidir. Bankı kullanan karakter, bankın tam ortasına oturmuştur. Bu nedenle de yanına bir başkasının oturması artık mümkün değildir, nitekim diğer karakter de oturmamıştır. Ek olarak oturma biçimi bankın elverdiği ölçüde rahat görünmektedir.

Allen'in 1995 yılında çektiği ve Türkçe'ye Sevimli Fahişe ${ }^{17}$ olarak çevrilen filminde de erkek karakter buluşma için gelecek bir kadını bankta beklemektedir. Kent mobilyası "beklemenin mekânı" olma işlevi yüklenmiştir.

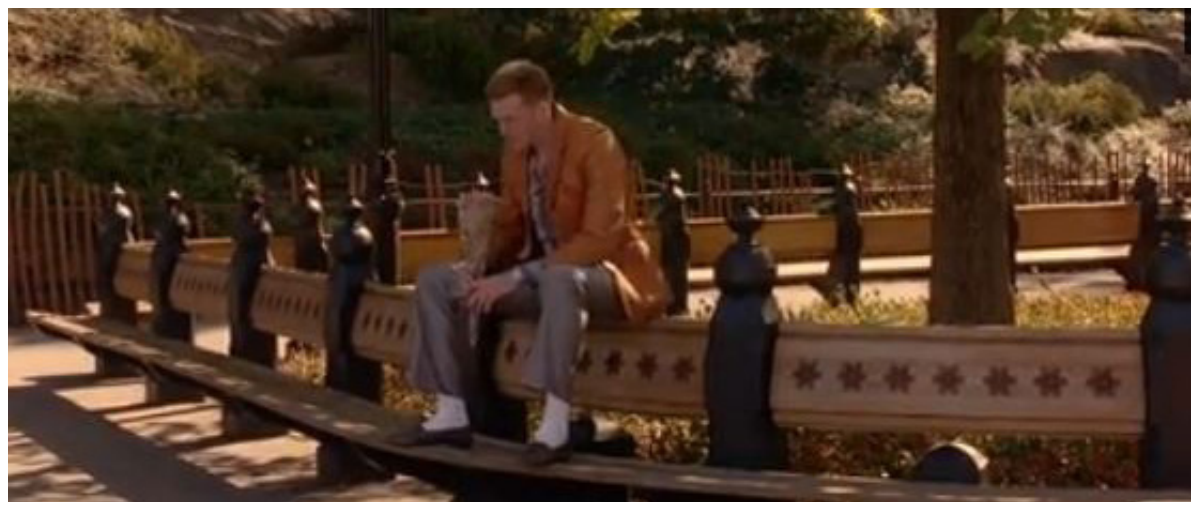

Resim.12. Sevimli Fahişe (1995)

17 Sevimli Fahişe (1995) Orijinal Adı: Mighty Aphrodite Yönetmen: Woody Allen, Senarist: Woody Allen Oyuncular: Woody Allen, Mira Sorvino, Helena Bonham Carter, Michael Rapaport, F. Murray Abraham, Süre: 95. dk Ülke: ABD Orijinal Dil: İngilizce 
Ancak burada çalışma kapsamında şimdiye değin Allen'ın kent mobilyası kullanımında değininmeyen bir kullanım modeli söz konusudur. Burada (Resim: 12) olduğu gibi oturan karakter, bankın formunu, kullanım biçimi ile değiştirmiştir. Bank tasarım amacı olan "oturma" eylemi için kullanılmış olsa da tasarımcının kullanımı öngördüğü biçimde kullanılmamıştır. Bankı kullanan kişi her ne kadar onun yönünü şeklini değiştiremese de kullanım biçimiyle ona bir direniş göstermiştir. Kentsel mekânda belirlenmiş yerlere belirlenmiş biçim ve şekillerde yerleştirilen kent mobilyaları bu belirlenmişlikleri nedeni ile içerisinde oluşacak iletişim biçimlerini de yönlendirmektedir. Çünkü bankın baktığı yön, kaç kişinin oturabileceği, bankların birbirlerine uzaklığı gibi etmenler iletişim biçimlerine yön vermektedir. Ancak Öztürk'ün (2012: 148) total mekânlarda mücadele ve direnişe dair çözümlemeler yaparken aktardığı gibi bireylerin direnişleri ürünlerin onlara dayatıldığı biçimler dışında kullanmaları olarak ortaya çıkmaktadır.

\section{b. "Yalnız"ın Mekânı Olarak Banklar}

Allen'ın bu çalışma kapsamında konu edilecek son filmi aynı zamanda da bu yazı yazıldığı sırada son filmi olan ve ayrıca son sahnesini bir kent mobilyasında tamamlayan 2013 yapımı Mavi Jasmine ${ }^{18}$ filmidir. Allen bu filminde hem maddi hem de manevi olarak her şeyini kaybetmiş bir kadının bocalamasının ve kaybetmişliğinin hikayesini anlatmaktadır.

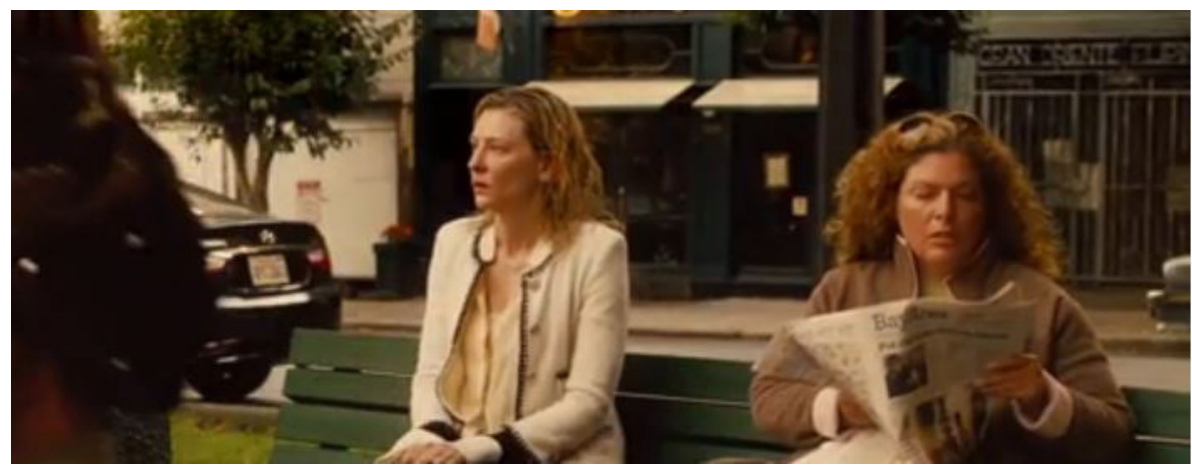

Resim.13. Blue Jasmine (2013)

Jasmine film boyunca yaşadığı hesaplaşmayı ve kendine sürekli telkinde bulunma savaşını bir kent mobilyasında kaybetmenin eşiğine gelir. Jasmine kardeşinin evinde kalmaktadır ve kardeşinin sevgilisi ile birlikte yaşama kararını duyduktan sonra taşınması gerekliliği ile karşı karşıya kalır. Bilinçsizce kardeşinin evinden çıkan Jasmine kentin bir kıyısına yerleştirilmiş bir banka oturur. Banka ilk oturduğunda orada zaten oturmakta olan bir kadınla karşılaşır ve kendi kendine mi yoksa o kadın ile mi konuştuğu belli olmayacak şekilde konuşmaya başlar. Bir süre sonra diğer kadın rahatsız olarak kalkar ve Jasmine için o kent mobilyası Allen tarafından yalnızlığın mekânına dönüştürülmüş olur. Tüm karşılaşma potansiyeline rağmen bank, Jasmine'nin akan ve kalabalık bir kentin ortasında yalnızlığının simgesine dönüşür.

18 Mavi Jasmine (2013): Orijinal Adı: Blue Jasmine Yönetmen: Woody Allen, Senarist: Woody Allen Oyuncular: Cate Blanchett, Alec Baldwin, Peter Sarsgaard, Charlie Tahan, Sally Hawkins, Süre: $98 \mathrm{dk}$ Ülke: ABD Orijinal Dil: İngilizce 


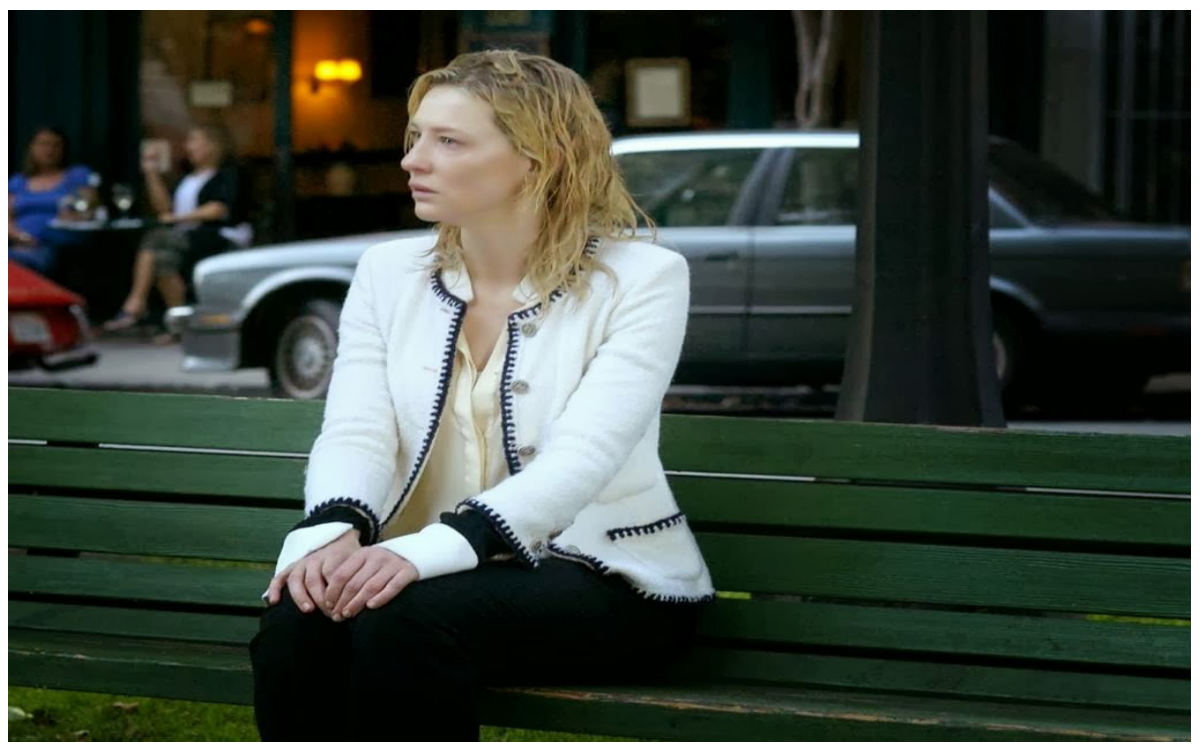

Resim.14. Blue Jasmine (2013)

Jasmine'nin beden duruşunu incelediğinde yine ellerini dizlerinin üzerinde buluşturduğunu, olabildiğince az yer kapladığını ve yalnızlığını daha iyi anlatması açısından iki yanı boş olan büyükçe bir bankta oturduğunu söylemek mümkündür.

\section{Sonuc}

Kentsel mekân, insanların birbirleri ile karşılaşmalarını sağlayacak potansiyeller içeren mekânlardan oluşmaktadır. Kent mobilyaları, bir yandan bireylerin kentsel mekânda karşılaşıp iletişim kurabilecekleri alanlar olabilirken bir yandan da kamusal alanda karşılaşmalardan uzaklaşıp bireyselleşebilecekleri alanlar olabilmektedirler. Kent mekânlarında dinleme intiyacını gidermeye de yarayan bu yerlerin tasarımları iletişim geliştirme olasılıklarına etki eder. Bu çalışma çerçevesinde ele alınan Woody Allen sinemasında banklar her ne kadar birer filmin parçası olarak görülseler de bankların düzenleri ve biçimleri gerçekle uyumludur. İncelediğimiz banklar gerçekten kent mekânında oldukları halleriyle kullanılmışlardır.

Bankların yerleşim biçimleri incelendiğinde birçoğunun birbirlerine uzak konumlanmış olmalarının, bu kullanım sırasında kişilerin birbirlerine yaklaşmalarına ve iletişim kurmalarına engel olduğu görülmüştür. Aynı şekilde bankların boyutları kullanan kişi sayısını belirlediğinden yeni karşılaşmalara yine olanak tanıması hususunda etkili olduğu gözlenmiştir. Çünkü bir banka en fazla üç kişi sığabilmekte ve eğer üç kişi oturacaksa dahi iletişimde mahrem alan mesafesi göz önüne alındığında bu üç kişinin tanıdık olmaları gerekmektedir. En fazla iki yabancının oturabileceği bu bankların, diğer banklara olan uzaklığı, birbirlerine olan açıları da potansiyel iletişimi zorlaştırmaktadır. Ancak yine de filmlerin çekildiği kentlerde kullanılan oldukça büyük ve karşılaşma intimali diğerlerine nazaran daha yüksek olan bank biçimleri de görülmüştür. Ve kent mobilyaları tüm bu özellikleri ile Allen sinemasında iletişim mekânı olma potansiyelini 
de korumaktadırlar. Bunun yanında banların kentsel kamusal mekânda birer özel alan duygusu yaratma özellikleri ile de "kamusal alan-özel alan geçişgenliği" yaratan mekânlardan biri olarak değerlendirilmeye uygundurlar. Son olarak yine bu kent mobilyalarının kullanımları açısından karakterlerin hikayedeki kişilikleri ile uyumlu olarak değişkenlikler göstermektedir. Örneğin zayıflığın ve açık olamamanın simgesi incelenen filmler ışığında elleri dizlerinin üzerine koyan karakterler olarak gözlenmiştir. Sinemada kent mobilyalarının kullanımını gözlemlemek ile gerçek kent mekânında kent mobilyalarının kullanımını gözlemlemek arasındaki en büyük fark sinemada incelenen karakterin hikayesini biliyorken, kent mekânında kent mobilyasını kullanan karakterin hikayesi ve onu o banka getiren nedenleri bilemiyor olmamızdır. Buna ek olarak gerçek kent mekânında yabancılar ile kent mobilyaları aracılığı ile karşılaşmak sinemadaki en azından Woody Allen sinemasındaki olasılıktan daha yüksektir. Bunun dışında Woody Allen sinemasında kent mobilyaları olabildiğince gerçekle uyumlu kullanılmış ve hikayenin içerisinde doğal birer unsur olarak sunulmuştur.

\section{Kaynakça}

Alkan, Ayten,(1999). "Özel Alan-Kamusal Alan Ayrımının Feminist Eleştirisi” AÜ SBF Dergisi. (Ankara: AÜ SBF Basımevi, 1999).

Arendt, Hannah (2000). İnsanlık Durumu. Çev., Bahadır Sina Şener. İstanbul: İletişim

Asiliskender, Barış (2002) "Mekân Kavramı", Okyanus Dergisi. 15-24.

Bayazıt, Nigan, (2003). “ístanbul İçin Kent Mobilyaları Denemesi”. II. Uluslararası Kent Mobilyaları Sempozyumu Bildiri Kitabı içinde. İstanbul : İstanbul Büyük Şehir Belediyesi Yayınları.

Bayrakçı, Oğuz (1991). "Kent Mobilyaları Tasarımında Kimlik Sorunu ve Kent Kimliği Iç̧indeki Yeri”. Kamu Mekânları Tasarımı ve Kent Mobilyaları Sempozyumu Kitabı içinde İstanbul

Bookchin, Murray (1999). Kentsiz Kentleşme Yurttaşlığın Yükselişi ve Çöküşü. Çev., Burak Özyalçın. . İstanbul: Ayrıntı

Clarke, David (1997). The Cinematic City. Routledge

Çakmaklı, Derya (1992). "Kentsel Çevrede Mekân ve Kentsel Mekân Kavramlarının İrdelenmesi”, Mimarlık ve Şehircilikte Mekân içinde, İstanbul: Yıldız Üniversitesi Yerleşme ve Mimarlık Bilimleri Uygulamalı Araştırma Merkezi.

Çubuk, Mehmet (1991) "Kamu Mekânları ve Kentsel Tasarım" , Kamu Mekânları Tasarımı ve Kent Mobilyaları Sempozyumu Kitabı içinde. İstanbul: 1991

Develioğlu, Ferit (1992). Osmanlıca-Türkçe Ansiklopedik Lûgat,. Ankara: Aydın,

Fırat, Serap (2002). "Kentsel Mekânda Kamusal Alan” Çağdaş Yerel Yönetimler. 4: 41-72.

Güneş, Serkan (2005). "Kent Mobilyası Tasarımından Disiplinler arası Etkileşim”. Planlama Dergisi 3: 92-95.

Göka, Şenol (2001). İnsan Mekân. İstanbul: Pınar.

Habermas, Jürgen (2004). "Kamusal Alan”. Kamusal Alan. Meral Özbek (der.) içinde. İstanbul: Hill. 
Habermas, Jürgen (2005). Kamusalığın Yapısal Dönüşümü. Çev., Mithat Sancar, Tanıl Bora. İstanbul: İletişim.

Keskin Gül (2008). "Kentleri Tanımlayan Mobilyalar" www.v3.arkitera.com/h34666-kentleritanimlayan-mobilyalar.html. 07.11.2016

Lefebvre, Henri (2009). State, Space,World Selected Essay. London: Minepolis.

Özbek, Meral (2004a)“Kamusal Alanın Sınırları”. Kamusal Alan. Meral Özbek (der.) içinde . İstanbul: Hill,

Özbek, Meral (2004b) "Giriş: Kamusal-Özel Alan, Kültür ve Tecrübe”, Kamusal Alan. Meral Özbek (der.) içinde . İstanbul: Hill,

Öztürk, Kutsal, "Kent Mobilyaları Tasarımında Bilgi İletimi Estetiği”, M.S.Ü. Mimarlık Fakültesi, Tasarımlar ve Uygulamalar Sempozyum Dizisi içinde (İstanbul: Mimar Sinan Üniversitesi, 1994).

Öztürk, Mehmet (1991). Sinemasal Kentler. İstanbul: İletişim.

Öztürk, Serdar (2012). Mekân ve İktidar: Filmlerle İletişim Mekânlarının Alt Politikası Ankara: Phoenix.

Sennett, Richard (2011). Ten ve Taş, Batı Uygarlığında Beden ve Şehir. Çev., Tuncay Birkan. İstanbul: Metis, 2011.

Shiel, Mark (2001). Cinema and The City,. Blackwell Publishers: Oxford.

Thompson, B. John (2008). Medya ve Modernite. Çev., Serdar Öztürk. İstanbul: Kırmızı.

Tümtaş, M. Sertaç (2012. Kent, Mekân ve Ayrışma. Ankara: Detay.

Ulusay Nejat, Kılıçbay Barış, "Görev İstanbul: Yabancı Filmlerde Bir Fantezi Kenti", TMMOB Ankara Şubesi Dergisi, Dosya 16, s. 20-25.

Urry, John (1999). Mekânları Tüketmek. Çev., Rahmi G. Öğdül . İstanbul: Ayrıntı. 